УДК: 159.9:613.8

DOI: $10.33099 / 2617-6858-2019-53-3-39-45$

Войтех О. НУОУ імені Івана Черняховського

ORCID ID 0000-0003-1387-3188

Войтех К. НУОУ імені Івана Черняховського

ORCID ID 0000-0003-4290-1766

\title{
ПСИХОЛОГІЧНИЙ СУПРОВІД ДІЯЛЬНОСТІ ВІЙСЬКОВОСЛУЖБОВЦІВ ПІД ЧАС ВИКОНАННЯ ЗАВДАНЬ У МІЖНАРОДНИХ ОПЕРАЦІЯХ 3 ПІДТРИМАННЯ МИРУ І БЕЗПЕКИ
}

\begin{abstract}
Стаття присвячена дослідженню актуальної проблеми психологічного супроводу діяльності військовослужбовців ЗС України у міжнародних операціях з підтримання миру та безпеки. Визначенню специффічних завдань миротворчої діяльності притаманних операціям з підтримання миру та безпеки у XXI столітті. Встановленню специифічних чинників негативного психологічного впливу на психіку військовослужбовців національного персоналу. Обгрунтуванню пропозицій 3 організації психологічного супроводу діяльності військовослужбовців під час виконання завдань в міжнародних операціях, як складової їх психологічного забезпечення.

В статті зосереджено увагу на важливості та актуальності аутогенних способів психологічної підтримки та самодопомоги. Запропонована система дієвих методів та технік психологічної самодопомоги.
\end{abstract}

Ключові слова: психологічний супровід; психіка; стійкість; готовність; профілактика; підготовка; операція з підтримання миру та безпеки.

Постановка проблеми у загальному вигляді. Серед пріоритетних завдань Збройних Сил України $€$ участь військовослужбовців в операціях 3 підтримання миру i безпеки, яка реалізується через співробітництво з $\mathrm{OOH}$, ОБСЕ, НАТО та $з$ провідними державами світу. Понад 300 військовослужбовців $3 \mathrm{C}$ України беруть участь у 8 міжнародних операціях з підтримання миру та безпеки як під приводом ООН та НАТО, так і у складі спільних миротворчих сил [1]. Залучення до міжнародних операцій 3 підтримання миру i безпеки військовослужбовців $3 С$ України у якості національного персоналу, складність завдань, небезпечні умови ї виконання ставить завдання щодо організації їх належного психологічного забезпечення.

Досвід проведення активної бойової діяльності військовослужбовців ЗС Украӥни яскраво продемонстрував, що ефективність застосування військ (сил) визначається не тільки методами підготовки особового складу, а, передусім, врахуванням психологічних факторів бойової діяльності, визначенням та прогнозуванням психологічних можливостей кожного військовослужбовця виконувати завдання в екстремальних умовах, підтриманням його психологічного стану безпосередньо в стресовій ситуації та забезпеченням своєчасного відновлення психіки після дії надінтенсивних стресових впливів [2, с.87].

Військовослужбовці, які виконують обов'язки в операціях з підтримання миру i безпеки переживають значні психічні навантаження, що можуть призводити до руйнування звичного сприйняття $\mathrm{i}$ поведінки, можуть спричиняти бойовий стрес. Останній характеризується складними змінами в емоційній сфері, самопочутті, діяльності, прагненнях, когнітивних стратегіях, людських стосунках.

Досвід миротворчих операцій останніх десятиріч переконливо свідчить, що умови виконання завдань в зонах збройних конфліктів впливає на психологічні якості, психофізіологічний стан, настрій, бойову активність особового складу. Наслідком психотравмуючих чинників операцій з підтримання миру $\mathrm{i}$ безпеки можуть бути психогенні втрати. Таким чином, актуальною проблемою постає психологічне забезпечення діяльності військовослужбовців залучених до складу національного персоналу. Одним із напрямків психологічного забезпечення є психологічний супровід, 


\section{Питання психології}

найважливішим елементом якого $\epsilon$ первинна психологічна допомога особовому складу під час виконання завдань у міжнародних операціях 3 підтримання миру і безпеки.

До наукового розв'язання проблеми психологічного супроводу та надання психологічної допомоги військовослужбовцям зокрема, в умовах повсякденної діяльності, бойової обстановки та після бою, вдавалися як зарубіжні, так і українські вчені, а саме: Н. Агаєв, В. Алещенко, А. Кардинер, Дж. Келлі, Б. Колодзін, М. Корольчук, Д. Лінді, В. Осьодло, Дж. Ротор, В. Стасюк, О. Сафін, О. Хміляр та інші. Проте, питання психологічного супроводу діяльності військовослужбовців під час виконання завдань у міжнародних операціях з підтримання миру і безпеки не стало предметом окремого дослідження, що й визначає його актуальність.

Мета статті полягає у визначенні особливостей психологічного супроводу діяльності військовослужбовців під час виконання завдань у міжнародних операціях з підтримання миру і безпеки.

Аналіз досліджень та публікацій. Теоретико-методологічним підгрунтям окресленої наукової проблеми $\epsilon$ фундаментальні психологічні дослідження структури особистості та її взаємозв'язку з діяльністю (Б. Ананьєв, О. Леонтьєв, С. Максименко, С. Рубінштейн,), теорії функціональних систем (П. Анохін, В. Клименко), системного підходу в психології (О. Конопкін, В. Марищук, М. Корольчук), ефективності діяльності в умовах професійного стресу (Г. Сельє, О. Саннікова, Г. Ложкін), визначення шляхів i засобів психологічного забезпечення військової діяльності в екстремальних умовах (О. Макаревич, В. Осьодло, В. Стасюк, 3. Кісарчук).

На основі узагальнення наукових підходів до розуміння психологічного супроводу, у межах нашого дослідження визначаємо його як комплекс заходів 3 підтримання оптимального стану психічного здоров'я військовослужбовців під час участі в операції з підтримання миру та безпеки, їх стійкості до впливу специфічних стресових чинників, психологічної готовності до виконання обов'язків миротворчої діяльності та запобігання виникненню негативних психологічних станів.

До процесу психологічного супроводу бойових дій військ у локальному воєнному конфлікті залучається широке коло фахівців. Однак при його реалізації у військових частинах найважливіша роль належить практичному психологу. У рамках його посадових обов'язків поєднуються елементи теоретичної, прикладної та практичної роботи, що реалізуються в дослідницькій, нормотворчій, консультативній і корекційній функціях [3].

Однак, особливість участі в операції 3 підтримання миру та безпеки у складі міжнародного персоналу полягає у відсутності фахових психологів в складі команд. Таким чином завдання психологічного супроводу вирішуються самими ж військовослужбовцями.

Враховуючи особливості миротворчої діяльності та підходи до організації психологічного супроводу бойової діяльності, що існують в ЗС України виокремлюємо наступні форми психологічного супроводу професійної діяльності особового складу під час виконання завдань за призначенням (участі в операції з підтримання миру та безпеки): психологічна профілактика; психологічна діагностика; психологічна регуляція та саморегуляція; опосередкований вплив на особистість військовослужбовців через відповідно спрямовану роботу з їх сім'ями; психологічне консультування; психологічна просвіта особового складу [3].

Використання цих форм дозволить системно та всебічно вирішувати питання психологічного супроводу, збереження психічного здоров'я миротворчого персоналу.

Поділяємо погляди вітчизняних науковців, що виокремлюють та систематизують низку методів психологічного супроводу професійної діяльності особового складу, зокрема: організаційні - планування, контроль за виконанням вимог, надання рекомендацій, підтримання сприятливих умов; емпіричні 


\section{Питання психології}

- включене та невключене спостереження, діагностування, спеціальні (соціометричні) дослідження, експертна оцінка, психологічна вправа (психотренінг), емоційно-вольова регуляція та саморегуляція, інформування, опитування, індивідуальна бесіда, переконання, навіювання, позитивний приклад, засудження, заохочення, подяка; опрацювання даних - аналіз отриманої інформації; інтерпретаційні інтерпретація отриманих результатів [4].

Аналіз наукових розвідок та керівних документів 3 питань психологічного супроводу бойової діяльності військовослужбовців засвідчив, що запропонований комплекс форм, методів та заходів являє собою технологічну систему, яка дозволяє управляти психологічним потенціалом військовослужбовців. Системність психологічного супроводу обумовлена наявністю структурних ознак багатоелементності, ієрархічності, системного взаємозв'язку і взаємної, обумовленості властивостей елементів, збереження на всіх етапах єдиного предмету - психічного здоров'я військовослужбовців, що $\epsilon$ системотворчим чинником. Реалізація заходів психологічного супроводу діяльності військовослужбовців має на меті розширення психологічних можливостей під час виконання службових завдань, збереження психічного здоров'я та створення передумов нормальної соціалізації та повернення військовослужбовців до функціонування в звичайних умовах.

\section{Виклад}

основного

змісту. Психологічний супровід діяльності військовослужбовців у ході миротворчої діяльності має виражені особливості в змісті наукового i практичного компонентів. Науковий компонент включає методологічний i прикладний аспекти. Методологічний аспект виявляється в науковому дослідженні психологічних закономірностей, умов і передумов успішних дій у операціях 3 підтримання миру та безпеки взагалі й у конкретній конфліктній події, зокрема, а також припускає вивчення характеру впливу на психіку військовослужбовців i психологію воєнних колективів соціальнополітичних, ергономічних i бойових обставин конфлікту. Важливим моментом тут є виявлення соціально-психологічних особливостей виконання завдань, сильних і слабких сторін у психологічній стійкості військовослужбовців.

Для визначення системи заходів психологічного супроводу діяльності військовослужбовців в операціях 3 підтримання миру та безпеки необхідно визначити фактори негативного психологічного впливу, що супроводжують миротворчу діяльність. Фахівці зосереджують увагу на розширенні спектру завдань в таких операціях у XXI ст. Зокрема зазначають, що «традиційні операції 3 підтримання миру та безпеки концентрувались на таких засадах та функціях як спостереження, нагляд, звітування (на основі патрулювань, контролювання технічних аспектів, використання статистичних даних); нагляд за припиненням вогню i підтримка механізму верифікації; створення буферних зон між конфліктуючими сторонами, то операції 3 підтримання миру та безпеки нового покоління (місії спостерігачів та сили 3 підтримання миру/миротворчі сили) виконують такі завдання: створення стабільного і безпечного середовища для того, аби держава змогла забезпечити безпеку i повагу до прав людини; сприяння політичному процесу i діалогу для створення легітимних інституцій управління; запровадження рамкових механізмів i координація зусиль усіх сторін, що беруть участь у процесі врегулювання ситуації; забезпечення безпеки при реалізації ключових управлінських рішень; координація зусиль установ системи ООН та неурядових організацій; скерування зусиль щодо політичного врегулювання» [6, с. 119].

Відповідно до завдань, які вирішують військовослужбовці в операціях 3 підтримання миру та безпеки їх небезпеки, загрози життю, раптовості та новизні, вчені виокремлюють систему чинників 


\section{Питання психології}

негативного впливу на психіку військовослужбовців та поділяють їх на дві групи, а саме:

до групи " $\mathrm{X}$ " належать: загроза життю (вигляд крові, важких поранень або смерті бойових товаришів, руйнування будівель чи бойової техніки, як правило, паралізує непідготовлену для холоднокровного сприймання цього психіку людини. Неадекватне сприймання загрози життю веде до помилок, до перенапруженості, до зриву діяльності); paптовість (ii вплив на психіку миротворців досягається за трьома основними параметрами: за часом, за місцем i за рішенням. При цьому, ініціатива у виборі часу, місця удару, здійснення маневру в умовах миротворчої місії належить противнику, діючому в зоні відповідальності підрозділу); новизна (між гарантією прогнозу і реальним розвитком бойової ситуації, як правило, виявляється розрив, який в ході виконання завдань $\epsilon$ джерелом дистресу. Причина цього полягає в невідповідності між розумінням ситуації особою, що приймає рішення, i реальним iї розвитком); монотонія від надлишку часу (монотонія в період тривалого очікування здатна дестабілізувати діяльність окремих миротворців для яких притаманні такі особливості характеру, як: демонстративність, збудливість, гіпертимність, екзальтованість); групова ізолящія (вимушена самотність при виконанні бойових завдань. Особливо важко переноситься екстравертами.);

До групи чинників "Y" належать: дефіцит часу на оцінку обстановки (час для прийняття рішення в умовах високої динаміки бою дуже обмежений. Ця обставина призводить до зростання психічної напруженості, набуваючи пригноблюючого для людини значення); підвищення темnу дій (вимагає від миротворців швидкості як моторних дій, так i приймання рішень. При цьому ефективність майбутнього рішення може бути забезпечена на підставі випереджального відображення, передбачення назріваючих подій); поєднання декількох видів діяльності одночасно (до них, перш за все, відносяться: а) аферентні операції сприймання інформації, отримання наказів i команд, контроль за результатами бойових дій; б) еферентні операції пов'язані із здійсненням прийнятих рішень: ціле-вказання, ціле-розподілення) [7, c. 42-43].

Екстраполюючи існуючі в $3 \mathrm{C}$ України підходи та заходи до психологічного супроводу виконання завдань за призначенням [5] на діяльність військовослужбовців в специфічних умовах миротворчої операції пропонуємо наступну систему заходів:

проведення інформативних заходів спрямованих на адаптацію до конкретних умов та особливостей (географічних, кліматичних, соціокультурних) миротворчої діяльності особового складу;

діагностика наявності, видів та рівнів психічних розладів у військовослужбовців на етапі відбору та підготовки до участі в операції;

корекція самосвідомості, самооцінки, самопочуття та бойової мотивації військовослужбовців, які отримали психічні розлади під час виконання завдань в операції з підтримання миру та безпеки;

профілактика розвитку бойових психічних травм (заходи скринінгу i моніторингу психологічного та соматичного стану військовослужбовців, забезпечення доступу як до безпосередньої психологічної допомоги (індивідуальне або групове консультування), так i дистанційної (телефонне консультування); особи, у яких виявляються гострі реакції на стрес, мають терміново отримувати невідкладну психологічну допомогу, 3 метою профілактики хронізації стресового розладу);

евакуація військовослужбовців із місць виконання завдань (у разі: неспроможності військовослужбовця виконувати функціональні обов'язки; неадекватної оцінки оточення, відсутності контакту; деморалізуючого впливу військовослужбовця на оточуючих; 


\section{Питання психології}

загрози 3 його боку для інших військовослужбовців);

встановлення фактів (ознак) страху та паніки, (виявлення фактів поширення занепадницьких настроїв та боротьби 3 ними);

встановлення інформації щодо психотравмуючих факторів службової діяльності (опис службово-бойової діяльності підрозділів; опис екстремальних умов виконання завдань служби (ситуації загрози життю); опис травматичних подій (коли військовослужбовець був учасником, свідком подій, які включають смерть, загрозу смерті 3 серйозними ушкодженнями, загрозу особистої фізичної цілісності або інших людей: загибель, поранення, травмування, полон);

ефективне поновлення фізичних сил військовослужбовців завдяки достатньому рівню відпочинку і харчування; особливу увагу слід приділяти гігієні сну;

попередження вживання особовим складом алкоголю та наркотичних речовин; психологічна взаємодопомога військовослужбовців (психологічне просвітництво на етапі підготовки до участі в операції).

Виходячи 3 обставин, які передбачають виконання завдань військовослужбовців зі складу національного персоналу у малих міжнаціональних групах найбільшої актуальності набувають аутогенні способи психологічної підтримки (самодопомоги). За умови якісного їх засвоєння, вони $\epsilon$ найбільш ефективним засобом регулювання психічної діяльності. Складна обстановка виконання завдань пред'являе до методів психічного саморегулювання жорсткі вимоги. По-перше, вони мають бути ефективними, тобто в короткий термін (3-5 хвилин) давати відчутний результат. Подруге, вони не мають мати побічних ефектів (млявість, розслабленість, зниження уваги, або навпаки, підвищення психічної напруги). Вважаємо, що цим вимогам відповідають способи саморегулювання, побудовані на основі дії механізмів взаємозв'язку типів дихання, тонусу скелетних м'язів і станів нервової i психічної систем людини. До них відносимо: метод статичного аутотренінгу; метод динамічного аутотренінгу; техніку дихання; складання власного «кодексу честі»; техніку подолання болю.

Висновки. Специфіка виконання військовослужбовцями завдань в міжнародних операціях 3 підтримання миру та безпеки полягає в діяльності під впливом низки негативних психологічних чинників, зокрема: загрози життю, раптовості, новизни, монотонії від надлишку часу, групової ізоляції, підвищення темпу дій, дефіциту часу, поєднання декількох видів діяльності одночасно та інших. Для запобігання психічних розладів у військовослужбовців під час тривалого перебування в умовах негативного психологічного впливу нами запропоновано комплекс заходів психологічного супроводу миротворчої діяльності, що включає як профілактичні так і заходи психологічної допомоги та самодопомоги. Для військовослужбовців, що входять до складу національного персоналу в міжнародних операціях найбільшої актуальності набувають аутогенні способи психологічної підтримки (самодопомоги), а саме: методи статичного та динамічного аутотренінгу;техніки дихання, складання власного «кодексу честі», подолання болю та інші.

Перспективи подальших досліджень вбачаємо в напрацюванні рекомендації 3 психологічної підготовки військовослужбовців до участі в міжнародних операціях 3 підтримання миру та безпеки та їх експериментальної перевірки.

\section{Список використаних джерел}

1. Назва з екрану: «Де діють українські миротворці: у МОУ розповіли про контингент і операціï» URL: https://www.ukrinform.ua/rubric-society/2496198-de-diut-ukrainski-mirotvorci-u-mourozpovili-pro-kontingent-i-operacii.html (Дата звернення: 10.11.2019). 


\section{Питання психології}

2. Романишин А., Бойко О., Богородицький Д. Психологія бою: діяльність командира підрозділу щодо підтримання морально-психологічного стану особового складу в ході бойових дій: навчально-методичний посібник. Львів : НАСВ, 2015. 322 с.

3. Стасюк В.В. Психологія локальних війн та збройних конфліктів: [Підручник для слухачів та студентів вищих навчальних закладів]. Київ : НАОУ, 2006. 570 с.

4. Агаєв Н.А., Скрипкін О.Г., Дейко А.Б., Поливанюк В.В., Еверт О.В. Алгоритм роботи військового психолога щодо психологічного забезпечення професійної діяльності особового складу Збройних Сил України (методичні рекомендації) / Міністерство оборони України, Наук.-дослід. центр гуманітарних проблем Збройних Сил України: Київ : НДЦ ГП ЗС України, 2016. 147 с.

5. Тимчасова інструкція щодо організації психологічного супроводження та психологічного відновлення військовослужбовців. / ГШ ЗС України, ГУ РОС, 2015.

6. Ковтун О.Ю. Миротворча діяльність ООН у XXI столітті. Актуальні проблеми міжнародних відносин. Київ : КНУ ім. Т.Г.Шевченка, Випуск 96 (Частина I), 2011. 118-122 с. URL: http://journals.iir.kiev.ua/index.php/apmv/article/viewFile/749/706 (Дата звернення: 12.11.2019).

7. Алещенко В.І. Психологічне забезпечення миротворчої діяльності військовослужбовців Збройних Сил України. Монографія. Харків, ХУПС. 2008. 238 с.

\section{References}

1. Nazva $\mathrm{z}$ ekranu: «De diiut ukrainski myrotvortsi: u MOU rozpovily pro kontynhent i operatsii»[Screen caption: "Where Ukrainian peacekeepers operate: told about contingent and operations at MDU"] URL: https://www.ukrinform.ua/rubric-society/2496198-de-diut-ukrainski-mirotvorci-u-mourozpovili-pro-kontingent-i-operacii.html (Data zvernennia: 10.11.2019). (in Ukrainian).

2. Romanyshyn A., Boiko O., Bohorodytskyi D. Psykholohiia boiu: diialnist komandyra pidrozdilu shchodo pidtrymannia moralno-psykholohichnoho stanu osobovoho skladu $\mathrm{v}$ khodi boiovykh dii: navchalno-metodychnyi posibnyk. [Psychology of combat: the activity of the commander to maintain the moral and psychological status of personnel during the combat activity: training manual.] Lviv : NASV, 2015. 322 c. (in Ukrainian).

3. Stasiuk V.V. Psykholohiia lokalnykh viin ta zbroinykh konfliktiv: [Pidruchnyk dlia slukhachiv ta studentiv vyshchykh navchalnykh zakladiv]. [Psychology of Local Wars and Armed Conflicts: [Textbook for students of university]]. Kyiv : NAOU, 2006. 570 c. (in Ukrainian).

4. Ahaiev N.A., Skrypkin O.H., Deiko A.B., Polyvaniuk V.V., Evert O.V. Alhorytm roboty viiskovoho psykholoha shchodo psykholohichnoho zabezpechennia profesiinoi diialnosti osobovoho skladu Zbroinykh Syl Ukrainy (metodychni rekomendatsii) [Algorithm of work a military psychologist on psychological support of professional activity of military personnel of the Armed Forces of Ukraine (methodical recommendations)] Ministerstvo oborony Ukrainy, Nauk.-doslid. tsentr humanitarnykh problem Zbroinykh Syl Ukrainy: Kyiv : NDTs HP ZS Ukrainy, 2016. 147 c. (in Ukrainian).

5. Tymchasova instruktsiia shchodo orhanizatsii psykholohichnoho suprovodzhennia ta psykholohichnoho vidnovlennia viiskovosluzhbovtsiv. [Interim Instruction on the organization of psychological support and psychological recovery of military personnel.] HSh ZS Ukrainy, HU ROS, 2015. (in Ukrainian).

6. Kovtun O.Iu. Myrotvorcha diialnist OON u KhKhI stolitti. [UN peacekeeping in the $21 \mathrm{st}$ century.] Aktualni problemy mizhnarodnykh vidnosyn. Kyiv : KNU im. T.H.Shevchenka, Vypusk 96 (Chastyna I), 2011. 118-122 c. URL: http://journals.iir.kiev.ua/index.php/apmv/article/viewFile/749/706 (Data zvernennia: 12.11.2019). (in Ukrainian).

7. Aleshchenko V.I. Psykholohichne zabezpechennia myrotvorchoi diialnosti viiskovosluzhbovtsiv Zbroinykh Syl Ukrainy. Monohrafiia. [Psychological support for peacekeeping activities of military personnel of the Armed Forces of Ukraine. Monograph.] Kharkiv, KhUPS, 2008. 238 c. (in Ukrainian).

\section{Резюме \\ Войтех А. НУОУ имени Ивана Черняховского \\ Войтех К. НУОУ имени Ивана Черняховского \\ ПСИХОЛОГИЧЕСКОЕ СОПРОВОЖДЕНИЕ ДЕЯТЕЛЬНОСТИ \\ ВОЕННОСЛУЖАЩИХ ПРИ ВЫПОЛНЕНИИ ЗАДАЧ В МЕЖДУНАРОДНЫХ ОПЕРАЦИЯХ ПО ПОДДЕРЖАНИЮ МИРА И БЕЗОПАСНОСТИ}

Статья посвящена исследованию актуальной проблемь психологического сопровождения деятельности военнослужащих ВС Украины в международных операциях по поддержанию мира и безопасности. Определению специфических задач миротворческой деятельности присущих 


\section{Питання психології}

операциям по поддержанию мира и безопасности в ХХІ веке. Установлению специфических факторов негативного психологического воздействия на психику военнослужащих национального персонала. Обоснованию предложений по организации психологического сопровождения деятельности военнослужаших при выполнении задач в международных операциях, как составляющей их психологического обеспечения.

В статье сосредоточено внимание на важности и актуальности аутогенных способов психологической поддержки и самопомощуи. Предложена система действенных методов и техник психологической самопомошчи.

Ключевые слова: психологическое сопровождение; психика; устойчивость; готовность; профилактика; подготовка; операция по поддержанию мира и безопасности.

\section{Summary}

Voitekh O. National Defense University of Ukraine named after Ivan Cherniakhovskyi

Voitekh K. National Defense University of Ukraine named after Ivan Cherniakhovskyi

\section{PSYCHOLOGICAL SUPPORT OF ACTIVITIES OF MILITARY PERSONNEL DURING THE TASKS OF PEACEKEEPING OPERATIONS}

Introduction. The article is devoted to the research of the actual problem of psychological support of the activity of military personnel of the Armed Forces of Ukraine in peacekeeping operations. Defining the specific tasks of peacekeeping that are inherent in peacekeeping operations in the 21st century.

Purpose. Determining the peculiarities of psychological support for the activities of military personnel during the tasks in peacekeeping operations.

Methods. Analysis of the peculiarities of peacekeeping activities of military personnel in peacekeeping operations, comparison and generalization of factors of negative psychological impact, systematization of measures of psychological support.

Results. The specific tasks of peacekeeping activities that are inherent in peacekeeping operations in the 21st century are identified. Specific factors of negative psychological influence on the psyche of military personnel of national personnel have been established. The proposals for the organization of psychological support for the activities of military personnel during the execution of tasks in peacekeeping operations as a component of their psychological support are substantiated.

Originality. The article focuses on the importance and relevance of autogenous methods of psychological support and self-help. The system of effective methods and techniques of psychological selfhelp is offered.

Conclusion. Specificity of military personnel performing tasks in operations is activity under the influence of a number of negative psychological factors, in particular: threats to life, suddenness, novelty, monotony from excess time, group isolation, increase of pace of action, shortage of activities and combinations of activities at the same time and others. To prevent mental disorders in military personnel during prolonged stay in the conditions of negative psychological impact, we have proposed a set of measures of psychological support for peacekeeping activities, which includes both preventive and psychological assistance and self-help. For military personnel who are members of national personnel in peacekeeping operations, the most relevant are the autogenous methods of psychological support (selfhelp), namely: methods of static and dynamic self-training, breathing techniques, drafting their own "code of honor", overcoming pain and others.

Key words: psychological support; psychics; stability; readiness; prevention; preparation; peacekeeping operation. 